\title{
Patient-related stressors and coping strategies in baccalaureate nursing students during clinical practice
}

\section{Stresory związane z pacjentem oraz sposoby radzenia sobie ze stresem studentów pielęgniarstwa podczas zajęć klinicznych}

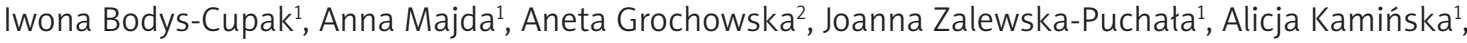 \\ Grażyna Kuzera ${ }^{3}$
}

${ }^{1}$ Faculty of Health Sciences, Jagiellonian University Medical College, Krakow, Poland Head of the Faculty: Prof. Tomasz Brzostek

2Department of Nursing, Institute of Health Protection, The State Higher Vocational School, Tarnow, Poland Head of the Department: Monika Łabuzek

${ }^{3}$ Institute of Health, State University of Applied Sciences, Nowy Sącz, Poland

Head of the Institute: Prof. Ryszard Gajdosz

Key words: coping, stress, nursing student.

Słowa kluczowe: radzenie sobie, stres, student pielęgniarstwa.

\begin{abstract}
Introduction: The first clinical experience of nursing students is of great importance in their professional development and the formation of professional competence. The education process is a stressful experience. This is due to the large emotional commitment, responsibility for health and life, and struggling with the problems of patients. To fully benefit from this experience, it is necessary that students successfully cope with stress.

Aim of the research: To assess patient-related stressors and coping behaviours of nursing students during clinical practice. Material and methods: The study was conducted among 786 first-year nursing students at universities in southern Poland in 2015 and 2016. Diagnostic survey and evaluation methods, as well as surveying and scaling techniques, were used, and the research tools were of the demographic characteristics form - Perceived Stress Scale (PSS-10), Inventory for Coping with Stress (Mini-COPE) to measure coping with stress. Verification of differences between variables was made using the MannWhitney test and Kruskal-Wallis test. The relationship between variables was determined by calculating the Spearman rank correlation and multidimensional logistic regression. The adopted level of significance was $\alpha=0.05$.

Results: Nursing students struggled with many difficult situations and experienced moderate to severe stress, presenting a variety of different coping strategies. As the stress level increased, the frequency of coping with difficult situations by using avoiding behaviour increased (rho $=0.195 ; p<0.0001$ ). Students in difficult situations more often relied on problem-focused strategies rather than emotion-focused strategies.

Conclusions: It is advised that nursing students develop active ways to deal with difficult situations, especially those students displaying helplessness and avoiding behaviours.
\end{abstract}

\section{Streszczenie}

Wprowadzenie: Pierwsze doświadczenie kliniczne studentów pielęgniarstwa ma ogromne znaczenie w ich rozwoju profesjonalnym i kształtowaniu kompetencji zawodowych. Proces edukacji jest stresującym doświadczeniem. Wynika to z dużego zaangażowania emocjonalnego, odpowiedzialności za zdrowie i życie oraz zmagania się z problemami chorych. Aby w pełni korzystać z tego doświadczenia, studenci muszą skutecznie radzić sobie ze stresem.

Cel pracy: Ocena czynników stresujących związanych z pacjentem i sposobów radzenia sobie ze stresem studentów pielęgniarstwa podczas zajęć praktycznych.

Materiał i metody: Badania przeprowadzono wśród 786 studentów pierwszego roku kierunku pieleggniarstwo (południowa Polska). Zastosowano metodę sondażu diagnostycznego i szacowania, technikę ankietowania i skalowania. Narzędziami badawczymi były: autorski kwestionariusz w formie ankiety, Skala odczuwanego stresu oraz Inwentarz do pomiaru radzenia sobie ze stresem. Weryfikacji różnic między zmiennymi dokonano za pomocą testu niezależności $\chi^{2}$, testu Manna-Whitneya oraz Kruskala-Wallisa. Związek między zmiennymi określono przez obliczenie korelacji rang Spearmana i wielowymiarowej regresji logistycznej.

Wyniki: Studenci pielęgniarstwa zmagali się z wieloma trudnymi sytuacjami i doświadczali stresu o natężeniu od umiarkowanego do wysokiego. Stosowali różne strategie radzenia sobie ze stresem. Wraz ze wzrostem poziomu stresu zwiększała 
się częstość radzenia sobie $\mathrm{w}$ trudnych sytuacjach poprzez podejmowanie zachowań unikowych (rho = 0,195; $p<0,0001$ ). W trudnych sytuacjach studenci częściej polegali na strategiach skoncentrowanych na problemie niż na strategiach ukierunkowanych na emocje.

Wnioski: Wskazane jest rozwijanie aktywnych sposobów radzenia sobie w trudnych sytuacjach przez studentów pielęgniarstwa, zwłaszcza tych wykazujących bezradność i zachowania unikowe.

\section{Introduction}

Nursing is considered to be one of the service professions and is also a vocation. Performing social services, which includes the profession of nurse, is considered one of the most stressful of environments for the individual. This is due to the high emotional commitment to connect with the patient, taking responsibility for the health and life of a human being, together with the struggle against the problems of the sick and their families. Predispositions to pursue the profession of nurse should be combined with appropriate personality skills and an ability to cope with stress, which involves making good decisions in difficult situations. Often, candidates for the profession of nursing follow a stereotypical image of the nursing profession.

First contact with their future profession in natural conditions is very important for students and is often decisive in their decision to stay on this particular course of studies. It occurs during practical classes within the subject "basics of nursing". These classes take place in health care facilities and are aimed at optimising nursing skills. Students improve skills such as hygienic and instrumental care, interpersonal communication, cooperation with the therapeutic team, organisation of work in the ward, and the realisation of tasks of the members of the therapeutic team. During this first practice, they are made aware that it is a profession burdened with stress, is patient related, and produces numerous environmental or interpersonal stressors.

Numerous previous studies have confirmed the occurrence of stressful situations during the education of nursing students [1-7]. Higher levels of stress together with more psychophysical symptoms were found among nursing students than among other medical students [8] because, although they face the same stressors as other students, they have more responsibility for preparing for clinical practice, which increases stress. Gibbons as well as Jimenez et al. proved that the greatest source of stress is for students to practice in the clinical environment $[9,10]$. They are struggling with interpersonal interactions and their lack of knowledge as well as uncertainty in the range of care skills. Also stressful for them is caring for the dying and the fear of failure. Some studies have found that stress increases with the progress of the teaching process, and experiencing high levels of stress by students can have a major impact on their professional future [10]. A little stress is motivating, whereas too high a level disturbs learning; furthermore, regarding the strategies used to deal with stress, there is great diversity between people - some take action to combat stress, others limit themselves to controlling their symptoms [11-13]. Studies have shown that students use different combinations of coping strategies in a variety of difficult situations from avoidance behaviours to problem solving $[13,14]$. Other studies point out that students use active (planning, acceptance, and problem solving) and passive (denial, alcohol use, behavioural disengagement) ways of dealing with stress $[9,15]$. Shiferaw et al. observed that the presence of various interpersonal, environmental, and academic stressors are closely linked to unhealthy coping strategies [16]. The ways of coping change throughout the learning process and may be dependent on individual stress tolerance [17-19]. Research by Hegge et al. has shown that positive coping strategies reduce the stress experienced by students [20]. Effective coping with stress is an important skill for students to develop, and improving this skill allows optimum performance in the future. Nurse educators should actively engage in solving students' difficulties, giving advice, and reflecting on their daily activities. To optimally benefit from clinical education experiences and develop a positive professional identity, it is essential that students learn to effectively cope with stress.

\section{Aim of the research}

The purpose of the work was to assess difficult situations related to patient care and how nursing students cope with stress during first clinical practice in a hospital ward.

\section{Material and methods}

Diagnostic survey and evaluation methods and surveying and scaling techniques were used. The research tools consisted of the demographics characteristics form, Stress Scale by S. Cohen, T. Kamarck, and R. Mermelstein, adapted by Z. Juczyński and N. Oginska-Bulik, and Inventory to measure coping with stress by Charles S. Carver, adapted by Z. Juczyński and N. Ogińska-Bulik [21].

The demographics characteristics form consisted of questions about age, sex, and stressful situations (stressors). The questionnaire included questions about the different situations faced by students at their first clinical classes - related to the patient, his/ her care, and communication with him/her or his/her family. The respondent indicated which situations are the most stressful for him. 
Perceived Stress Scale-10 (PSS-10) was used to assess the severity of stress related to one's own situation over the preceding month. It contained 10 questions about subjective feelings related to personal problems and events. For each question, the subject responded by indicating on a five-step scale (from "never" to "very often"). The overall score was the sum of all points, with a theoretical distribution from 0 to 40 , and the results were transformed into standardised units (stens 1 to 10) and interpreted according to the Scale key. A score between 1 and 4 stens is a low score, from 7 to 10 stens is high, and between 5 and 6 stens is an average score.

The Inventory for coping with stress (Mini-COPE) has been used to evaluate typical ways of reacting and feeling in situations of severe stress. It consisted of 28 statements that included 14 strategies for coping with stress, which were divided into seven factors: Active Coping, including the strategies of Active Coping, Planning, and Positive Revalidation; Searching Support, including Finding Emotional Support and Finding Instrumental Support; Helplessness, including Psychoactive Substance Abuse, Abstinence, and Blaming Yourself; and Avoidance behaviours, including Dealing with Something Else, Denying, and Unloading Conversely. The strategies of Turn Towards Religion, Acceptance, and Sense of Humour were seen as independent factors. One of the four possible answers for each statement was one of four possibilities ranging from: I've almost never done this to almost always. The analysis of the results also distinguishes strategies focused on the problem, which included Active Coping, Planning, Instrumental Support Search, and Emotional-Focused Strategies, Emotional Support Search, Religion, and Denial.

The study covered 786 people studying nursing in their first year of first-degree studies at the Faculty of Health Sciences at the Jagiellonian University and at the State Higher Vocational Schools in Tarnów, Nowy Sacz, and Nowy Targ. The study was conducted in 2015 and 2016. Students were included in the study if: 1) they were students of first-degree studies in the field of nursing, 2) they studied in the first year of study, and 3) they completed practical courses on the subject of the Foundations of Nursing.

\section{Statistical analysis}

Questionnaires received from respondents were evaluated individually and checked for completeness; the data were then coded, entered into the database, and processed using IBM SPSS Statistics 20 for Windows. Verification of differences between variables was made using the Mann-Whitney test and KruskalWallis test and multidimensional logistic regression. The relationship between variables was determined by calculating the Spearman rank correlation and multidimensional logistic regression. The adopted level of significance was $\alpha=0.05$.

\section{Ethical considerations}

The research was approved by the Bioethics Committee - No. of approval: 122.6120.193.2015. Students were informed of the confidentiality and anonymity of the study, that their participation was voluntary, and that they may cease to cooperate at any time during the study.

\section{Results}

Most of the students tested (94.1\%) were women. Respondents were between 19 and 35 years old (mean \pm SD: $20.52 \pm 1.82$ ). The mean age of men (mean \pm SD: $21.26 \pm 2.51)$ was significantly higher $(p=0.002)$ than the mean age of women (mean \pm SD: $20.47 \pm 1.76$ ). Daily difficulties during practical classes were encountered by $5.5 \%$ of the students, quite often $54.5 \%$, while $38.2 \%$ of respondents felt that difficult situations were rare.

The difficult situations for students during first clinical practice were different. The most difficult was contact with suffering patients, the least difficult one was feeding the patient (Table 1).

Women significantly more often than men assessed as difficult the inability to provide effective help to the patient $(p=0.009)$ and the inability to deal with suffering $(p<0.001)$. Younger persons $(\mathrm{M}=20.47)$ significantly more frequently than older ones $(\mathrm{M}=20.88)$ reported as difficult the serious health condition of the patient $(p=0.001)$. Similarly, the younger students $(M=20.12)$ more often than the older students $(\mathrm{M}=20.6)$ indicated that it was difficult for them to perform hygienic activities ( $p=0.004)$.

Results of the PSS-10 Scale showed that a low level of stress was experienced by $17.8 \%$ of the respondents,

Table 1. Stressful situations for students during first clinical practice

\begin{tabular}{|lc|}
\hline Types of stressful situations & $\%$ \\
Contact with suffering patients & 35 \\
Severe health condition of the patients & 34.4 \\
Inability to provide effective help to the patient & 30.5 \\
Hygienic activities & 17.8 \\
Lack of satisfaction of the patient and his/her & 14.1 \\
family with the assistance provided & \\
Patient questions on health and care & 13.7 \\
Workstation preparation & 12.7 \\
Patient interviews & 11.7 \\
Life measurements & 8.8 \\
First contact with the patient & 8.4 \\
Close contact with the patient & 7.6 \\
Feeding the patient & 7.3 \\
\hline
\end{tabular}


an average level by $26.7 \%$ of the students, while $55.5 \%$ of respondents indicated they were experiencing severe stress. Slight differences suggested that a higher level of stress was experienced by women (56.1\%) than by men (30.4\%). Assuming the level of stress as point values (0-40 points), the differences between the groups were statistically significant $(p=0.002)$ because the PSS10 scores were higher for women $($ mean \pm SD: $19.88 \pm 6.06)$ than for men (mean \pm SD: $17.74 \pm 6.97$ ). The age of the subjects did not affect the level of stress experienced. With the increase in the frequency of difficulties encountered during practical training, the level of stress increased, with the lowest among those with rare difficulties $(M=19.63)$ and the highest in those who were exposed to such difficulties daily $(M=21.33)$. Differences between occurrences of difficulty and stress were not statistically significant.

Mini-COPE scores showed that students in the most difficult situations chose a coping strategy based on active coping $(\mathrm{M}=2.09)$, seeking emotional support $(\mathrm{M}=2.04)$, and planning $(\mathrm{M}=2.04)$. To a lesser degree, they coped by seeking instrumental support $(\mathrm{M}=1.98)$. Detailed results are shown in Table 2 .

It has been shown that older people were less likely to seek support in stressful situations (both emotional and instrumental support). People with higher stress levels in stressful situations were more inclined to deal with something else, deny, unload, take psychoactive substances, stop activities, or blame themselves. It was found, however, that those who experienced lower stress (lower scores on PSS-10) were more likely to cope with strategies such as active cop- ing, positive revalidation, and acceptance. As the level of stress increased, the frequency of coping by taking on avoidance behaviours increased (rho $=0.195$; $p<0.0001$ ) (Table 3).

Minor differences indicated that the planning strategy was more often selected by women than by men $(\mathrm{M}=2.03, \mathrm{M}=1.86, p=0.04)$. In the case of severe illness, the most commonly chosen strategies were active coping $(\mathrm{M}=2.10)$, followed by planning $(\mathrm{M}=2.05)$, and seeking instrumental support $(\mathrm{M}=04)$. In cases of difficulty in contacting the patient, the students most often chose active coping $(\mathrm{M}=2.11)$ or sought emotional support $(\mathrm{M}=2.06)$. They also sought emotional support $(\mathrm{M}=1.95)$ or planned activities $(\mathrm{M}=1.94)$ in cases of difficulty in close contact with the patient. An inability to provide effective help to the patient most often led to active coping $(\mathrm{M}=2.12)$, seeking emotional support, and planning $(\mathrm{M}=0.4)$. Performing hygienic activities in intimate areas of the body most often mobilised respondents into active coping $(\mathrm{M}=2.07)$ and planning $(\mathrm{M}=2.05)$. People who indicated these activities as difficult, significantly more often than others coped by using psychoactive substances $(\mathrm{M}=0.62$, SD $=0.84, p=0.002$ ) or by cessation of activities (mean \pm SD: $0.98 \pm 0.84, p=0.02$ ). Multivariate regression analysis confirmed that students in these situations were significantly more likely to be helpless $(\mathrm{OR}=1.64$, $p=0.01)$. A patient's lack of satisfaction with the obtained assistance resulted in most frequent choosing of strategies for active coping $(\mathrm{M}=2.14)$ or emotional support $(\mathrm{M}=2.10)$. Questions from patients about health conditions led to seeking instrumental support

Table 2. Strategies for dealing with stress in nursing students

\begin{tabular}{|lccccccc|}
\hline Strategies & Mean & SD & Min. & Max. & $\begin{array}{c}\text { I quartile } \\
\text { (median) }\end{array}$ & $\begin{array}{c}\text { II quartile } \\
\text { (median) }\end{array}$ & $\begin{array}{c}\text { III quartile } \\
\text { (median) }\end{array}$ \\
Active coping & 2.09 & 0.64 & 0 & 3 & 2 & 2 & 2.5 \\
Planning & 2.02 & 0.70 & 0 & 5.5 & 1.5 & 2 & 2.5 \\
Positive revalidation & 1.70 & 0.76 & 0 & 5 & 1 & 2 & 2 \\
Acceptance & 1.86 & 0.74 & 0 & 9 & 1.5 & 2 & 2.5 \\
Sense of humour & 1.07 & 0.79 & 0 & 9 & 0.5 & 1 & 1.5 \\
Return to religion & 1.34 & 1.01 & 0 & 9 & 0.5 & 1.5 & 2 \\
Seeking emotional support & 2.04 & 0.72 & 0 & 3 & 1.5 & 2 & 2.5 \\
Seeking instrumental support & 1.98 & 0.73 & 0 & 5 & 1.5 & 2 & 2.5 \\
Handling something other & 1.75 & 0.73 & 0 & 4.5 & 1.5 & 2 & 2 \\
Denial & 0.81 & 0.77 & 0 & 3 & 0 & 0.5 & 1.5 \\
Unloading & 1.48 & 0.73 & 0 & 5.5 & 1 & 1.5 & 2 \\
Use of psychoactive substances & 0.43 & 0.72 & 0 & 3 & 0 & 0 & 1 \\
Cessation of actions & 0.82 & 0.72 & 0 & 5.5 & 0 & 1 & 1.5 \\
Blaming yourself & 1.50 & 0.85 & 0 & 5.5 & 1 & 1.5 & 2 \\
\hline
\end{tabular}

SD - standard deviation, Min. - minimum, Max. - maximum. 
Table 3. Coping strategies, age of respondents, and the level of stress experienced by them

\begin{tabular}{|lcccc|}
\hline Coping strategies & \multicolumn{2}{c}{ Age } & \multicolumn{2}{c|}{ Stress level } \\
\cline { 2 - 5 } & rho & $P$-value & rho & $P$-value \\
Active coping & -0.031 & 0.3849 & -0.119 & 0.0008 \\
Planning & -0.036 & 0.3150 & -0.045 & 0.2037 \\
Positive revalidation & 0.010 & 0.7795 & -0.127 & 0.0003 \\
Acceptance & -0.024 & 0.5061 & -0.071 & 0.0481 \\
Sense of humour & 0.046 & 0.1993 & -0.013 & 0.7209 \\
Return to religion & -0.015 & 0.6789 & 0.010 & 0.7857 \\
Seeking emotional support & -0.096 & 0.0069 & -0.047 & 0.1874 \\
Seeking instrumental support & -0.079 & 0.0270 & 0.004 & 0.9170 \\
Handling something other & -0.016 & 0.6579 & 0.108 & 0.0024 \\
Denial & 0.031 & 0.3872 & 0.134 & 0.0002 \\
Unloading & -0.048 & 0.1777 & 0.184 & $<0.0001$ \\
Use of psychoactive substances & 0.062 & 0.0804 & 0.148 & $<0.0001$ \\
Cessation of measures & 0.068 & 0.0559 & 0.241 & $<0.0001$ \\
Blaming oneself & -0.018 & 0.6206 & 0.290 & $<0.0001$ \\
\hline
\end{tabular}

rho-Spearman rank correlation, $p$ - level of significance.

$(\mathrm{M}=1.99)$ and active coping $(\mathrm{M}=1.98)$. In cases where the students found it difficult to perform the measurements, they undertook an active coping strategy $(\mathrm{M}=2.20)$ and then sought support $(\mathrm{M}=2.07)$. The necessity of feeding the patient and experiencing this situation as difficult led to more frequent use of the strategy of active coping $(\mathrm{M}=2.18)$ followed by planning $(\mathrm{M}=2.02)$. In the case of difficulties in preparing the patient for medical procedures, the students most often took to active coping strategies $(\mathrm{M}=2.12)$ and then sought instrumental support $(\mathrm{M}=2.05)$.

In addition, multidimensional logistic regression showed that students had a significantly greater chance of taking evasive behaviour with patients with severe disease $(\mathrm{OR}=1.06, p=0.81)$, contact with the patient $(\mathrm{OR}=1.05, p=0.86)$, physical contact with the patient $(\mathrm{OR}=1.02, p=0.94)$, lack of patient's satisfaction ( $\mathrm{OR}=1.33, p=0.23)$, health status questions $(\mathrm{OR}=1.33$ taking measurements $(\mathrm{OR}=1.24, p=0.45)$, and patient feeding $(\mathrm{OR}=1.46, p=0.22)$, which they considered stressful.

\section{Discussion}

Nursing students face a variety of difficult situations, especially during their first practical classes in the ward, and the diversity of these situations determines the different ways of coping with stress. In our studies, it was shown that the difficult situations for students were those which involved the following: contact with suffering (35.0\%), severe condition of the patient (34.4\%), and lack of effective help provided to the patient (30.5\%). The results of the Kaneko and Momino study showed that, for Japanese nursing students, stress factors included performing hygiene maintaining activities and interpersonal interactions with their family members or interdisciplinary team members [4]. The authors of other studies $[9,10]$ have confirmed that students, in addition to struggling with interpersonal stress, reported stressfulness in taking care of patients, caring for a dying patient, or fear of failure. Sayedfatemi et al., when evaluating the stressors for nursing students, demonstrated that first-year nursing students, when compared with the students of the fourth year, identified more interpersonal and environmental stressors [1]. Shiferaw et al. showed that the most common stressors for students were interpersonal factors [16]. They observed that the occurrence of various interpersonal, environmental, and academic stressors was closely linked to unhealthy coping strategies. More than half of the students in their studies experienced severe stress. Slight differences suggested that higher levels of stress were felt more often by women than by men. Similar results were obtained by other authors [22-24].

Students adopt diverse coping strategies in difficult situations. In our own research, it was shown that they most often used a strategy based on active coping, emotional support, and planning. Similarly, research conducted among nursing students in Jordan showed that the most common way to cope with difficulties during clinical practice was by searching for a solution to the problem [14]. However, Żuralska et al. showed that nursing students, more often than obstetric students, in difficult situations preferred a style focused 
on task and seeking social contact [25]. On the other hand, midwives, unlike nurses, preferred a style that focused on emotions. Okumura et al. and Suga et al. described that avoidance behaviours allow students to cope with stress in relationships with a patient in a new clinical environment [18, 19]. In their studies, students were least likely to cope in difficult situations through the use of psychoactive substances. Similar results were obtained by Fornés-Vives et al. [17]. The results of the Szczyrba-Maron study showed that $25 \%$ of nursing students in difficult situations used pharmacological agents, i.e. sedative or stimulant tablets [26]. For $15 \%$ of those tested, alcohol was consumed as a remedy. Using alcohol and smoking as a way of coping in difficult situations amongst medical students has also been confirmed by Guthrie et al. and Ashton and Kamali [27, 28]. Sayedfatemi et al. determined that nursing students in Iran in the most difficult situations are seeking solutions following the principles of Islamic religion and culture (mutual respect, respect for the family, religion) [1]. They also found that smoking or use of alcohol or drugs were the least common ways of responding to stress. The results of the study conducted by Kaneko and Momino (2015) allowed them to ascertain that in a stressful situation students displayed a worsening mood and a passive attitude, which was manifested by lack of activity in seeking help to solve problems [4]. Results of the study by Hirsch et al. showed that the most prevalent coping strategies used by nursing students were denial of problems and escape-avoidance, both of which are ineffective ways of dealing with stressful situations [29]. Self-reported studies have also shown that students who use avoidance behaviours felt a higher level of stress than others. Confirmation of these dependencies can be found in the results of research by Alzayyat and Al-Gamal [30]. Most of the respondents in the study conducted by Shiferaw et al. coped with stress through positive thinking, while the most common unfavourable way to react was blaming oneself [16]. Similarly, Yildiz Findik et al. observed that nursing students showed passive coping strategies despite high levels of stress [31]. Alzayyat and Al-Gamal found that students in Jordan, who used evasion or relocation strategies, felt a higher level of stress [30]. Most students in medical studies, in research conducted by Niknami et al. in Iran, used a coping strategy relying on focusing on a problem [32]. Self-reported studies have shown that students in difficult situations seek social and instrumental support. Students from Korea also sought social support and attempted to solve the problem [33]. The most commonly used stress management strategies for students in Saudi Arabia were, first of all, blaming themselves, then, seeking support and turning to religion [22]. Other authors have confirmed that the leading, as well as the most positive, strategy for coping with stress by students was to seek social support [34, 35].

\section{Limitations of the study}

The main limitations of the study are related to areas of data collection methods. Data collection was undertaken at one point in time rather than longitudinally. The characteristics of the participants - young people, mainly women - could represent a bias.

\section{Conclusions}

During practical training on a hospital ward:

- difficult situations often appeared in slightly over half of the nursing students; the most frequent were contact with a suffering patient, severe health condition of the patient, and lack of ability to provide effective assistance to the patient;

- most nursing students experienced moderate or severe stress;

- nursing students adopted different coping strategies, the most common being active coping and seeking support.

In nursing students, the frequency of avoidance behaviours increased significantly as the level of stress increased. Awareness of difficult situations for nursing students will help to make educators more aware and thereby facilitate better support for the students. It also gives them the ability to control how students cope with stressful situations and motivates them to adopt active strategies for coping with difficulties. It is very important to develop active ways to deal with difficult situations in students, especially those who display helplessness and avoidance behaviour. Nurse educators need to consider how student experiences might contribute to potential distress and should provide social support by giving students constructive feedback. It is necessary to address the stress experienced by nursing students and to implement training that focuses on coping with stress into the nursing curriculum. The present study significantly extends prior research on other stressors and the associations between them and changes in student coping methods and stress levels.

\section{Conflict of interest}

The authors declare no conflict of interest.

\section{References}

1. Sayedfatemi N, Tafreshi M, Hagani H. Experienced stressors and coping strategies among Iranian nursing students. BMC Nurs 2007; 6: 11.

2. Eswi AS, Raadi S, Youssri H. Stress/stressors as perceived by Baccalaureate Saudi Nursing Students. Middle-East J Sci Res 2013; 14: 193-202.

3. Akhu-Zaheya LM, Shaban IA, Wejdan AK. Nursing students' perceived stress and influences in clinical performance. J Adv Nurs Stud 2015; 4: 44-48.

4. Kaneko S, Momino K. Stress factors and coping behaviours in nursing students during fundamentals clinical training in Japan. Int J Nurs Clin Pract 2015; 2: 138-144. 
5. Reeve K, Shumaker CJ, Yearwood EL, Crowell NA, Riley JB. Perceived stress and social support in undergraduate nursing students' educational experiences. Nurse Educ Today 2013; 33: 419-424.

6. Wolf L, Stidham AW, Ross R. Predictors of stress and Coping Strategies of US accelerated vs. generic baccalaureate nursing students: an embedded mixed methods study. Nurse Educ Today 2015; 35: 201-205.

7. Bodys-Cupak I, Majda A, Zalewska-Puchała J, Kamińska A. The impact of a sense of self-efficacy on the level of stress and the ways of coping with difficult situations in Polish nursing students. Nurse Educ Today 2016; 45: 102-107.

8. Beck CT. Nursing students' experiences caring for dying patients. J Nurs Educ 1997; 36: 408-415.

9. Gibbons C. Stress, coping and burn-out in nursing students. Int J Nurs Stud 2010; 47: 1299-1309.

10. Jimenez C, Navia-Osorio PM, Diaz CV. Stress and health in novice and experienced nursing students. J Adv Nurs 2010; 66: 442-455.

11. Jimenez J, Sanchez-Laguna JL, Jimenez-Linde IM. Coping and health in novice and experienced nursing students during clinical practice: a descriptive, differential and correlational analysis. J Nurs Educ Pract 2013; 3: 152-164.

12. Cherkil S, Gardens SJ, Soman DK. Coping styles and its association with sources of stress in undergraduate medical students. Indian J Psychol Med 2013; 35: 389-393.

13. Chan CK, So WK, Fong DY. Hong Kong baccalaureate nursing students`stress and coping strategies in clinical practice. J Prof Nurs 2009; 25: 307-313.

14. Shaban IA, Khater WA, Akhu-Zaheya LM. Undergraduate nursing students' stress sources and coping behaviours during their initial period of clinical training: a Jordanian perspective. Nurse Educ Pract 2012; 12: 204-209.

15. Yamashita K, Saito M, Takao T. Stress and coping styles in Japanese nursing students. Int J Nurs Pract 2012; 18: 489-496.

16. Shiferaw H, Anand S, Nemera G. Stress and coping strategies among generic B.Sc. nursing students of Jimma University, South West Ethiopia. Int J Rec Adv Mult Res 2015; 2: 511-517.

17. Fornés-Vives J, Garcia-Banda G, Frias-Navarro D, RosalesViladrich G. Coping, stress, and personality in Spanish nursing students: a longitudinal study. Nurse Educ Today 2016; 36: 318-323.

18. Okumura R, Suzuki T, Bai Y, Mukawa K. Stress coping ability in nursing students: studies on the influence factor of Sense of Coherence (SOC). Jpn Hosp 2012; 31: 71-79.

19. Suga K, Usami C, Oguro Y, Sakakibara C, Ishii N. Relationship between sense of coherence and stress coping strategy in nursing students: changes before and after clinical training. Med Biol 2011; 155: 424-432.

20. Hegge M, Larson SV. Stressors and coping strategies of students in accelerated baccalaureate nursing programs. Nurse Educ 2008; 33: 26-30.

21. Juczyński Z, Ogińska-Bulik N. Narzędzia pomiaru stresu i radzenia sobie ze stresem. Pracownia Testów Psychologicznych, Warsaw 2009.

22. Bamuhair SS, Al Farhan AI, Althubaiti A, Agha S, Rahman S, Ibrahim NO. Sources of stress and coping strategies among undergraduate medical students enrolled in a problem-based learning curriculum. J Biomed Educ 2015; 2015: 575139.
23. Elzubeir MA, Elzubeir KE, Magzoub ME. Stress and coping strategies among Arab medical students: towards a research agenda. Educ Health 2010; 23: 355-370.

24. Fernandes Pereira FG, Nunes Caldini L, Di Ciero M, Afio Caetano J. Assessment of stress in the inclusion of nursing students in hospital practice. Invest Educ Enferm 2014; 32: 430-437.

25. Żuralska R, Majkowicz M, Gaworska-Krzemińska A. Psychologiczna ocena stylów radzenia sobie ze stresem a cechy osobowości studentów Gdańskiego Uniwersytetu Medycznego. Probl Piel 2012; 20: 240-246.

26. Szczyrba-Maroń B. Strategie radzenia sobie ze stresem w grupie studentów pielęgniarstwa z uwzględnieniem korzystania ze środków psychoaktywnych. Probl Piel 2010; 18: 455-460.

27. Guthrie EA, Black D, Shaw CM, Hamilton J, Creed FH, Tomenson B. Embarking upon a medical career: psychological morbidity in first-year medical students. Med Educ 1995; 29: 337-341.

28. Ashton $\mathrm{CH}$, Kamali F. Personality, lifestyle, alcohol and drug consumption in a sample of British medical students. Med Educ 1995; 29: 187-192.

29. Hirsch CD, Barlem ELD, Tomaschewski-Barlem JG, Figueira AB, Lunardi VL, Oliveira ACC. Predictors of stress and coping strategies adopted by nursing students. Acta Paul Enferm 2015; 28: 224-229.

30. Alzayyat A, Al-Gamal E. Correlates of stress and coping among Jordanian nursing students during clinical practice in psychiatric/mental health course. Stress Health 2016; 32: 304-312.

31. Yildiz Findik U, Ozbas A, Cavdar I, Yildizeli Topcu S, Onler E. Assessment of nursing students' stress levels and coping strategies in operating room practice. Nurse Educ Pract 2015; 15: 192-195.

32. Niknami M, Dehghani F, Bouraki S, Kazemnejad E, Soleimani R. An assessment of the stressors and ways of coping in Iranian medical sciences students. Iran J Nurs Midwifery Res 2015; 20: 521-525.

33. Mi-Ran K, Su-Jeong H. Nursing students' emotional intelligences and doping strategies. Adv Sci Technol Lett 2015; 88: 53-56.

34. Lo R. A longitudinal study of perceived level of stress, coping and self-esteem of undergraduate nursing students: an Australian case study. J Adv Nurs 2002; 39: 119-126.

35. Gibbons C, Dempster M, Moutray M. Stress, coping and satisfaction in nursing students. J Adv Nurs 2011; 67: 621-632.

\section{Address for correspondence:}

\section{Iwona Bodys-Cupak $\mathrm{PhD}$}

Faculty of Health Sciences

Jagiellonian University Medical College

ul. Michałowskiego 12, 31-126 Krakow, Poland

Phone: +48 512396382

E-mail: i.bodys-cupak@uj.edu.pl 